\title{
PENGARUH PRODUK, HARGA, TEMPAT, PROMOSI RITEL MODERN TERHADAP KEBERLANGSUNGAN USAHA RITEL TRADISIONAL DI GRESIK'1)
}

\author{
Ongky Martha Dwiyananda \\ Mahasiswa Program Studi S 1Ekonomi Islam - Fakultas Ekonomi dan Bisnis-Universitas Airlangga \\ Email: ongkymartha@yahoo.co.id \\ Imron Mawardi \\ Departemen Ekonomi Syariah - Fakultas Ekonomi dan Bisnis - Universitas Airlangga \\ Email: ronmawardi@yahoo.co.id
}

\begin{abstract}
:
This research was aimed to examine the effect of product, price, place and promotion modern retail to the business continuity of traditional retail business in Gresik. This study used questionnaires in making primary data and quantitative approaches. Tests carried out using multiple linear regression, where the dependent variable $(Y)$ is the business continuity of traditional retail business and the independent variable $(X)$ is the product, price, place, promotion of modern retail. This research sample selected using purposive technique. The sample was 50 traditional retailers radius of two kilometers of modern retail in Gresik.

Based on $F$ test results showed that the product, price, place and promotion of modern retail simultaneously significant effect on the sustainability of traditional retail businesses. While the t test results showed that it was only on the variable product, place and promotion that has a significant influence on the sustainability of traditional retail business while at variable rates have no significant effect on the sustainability of traditional retail businesses. As we know that modern retail has the advantage of varied products, strategic location and attractive promotion of the suggestions from researchers that the traditional retailers are more creative and innovative in marketing their products and provide better service to the consumer so that the business can continue to compete with modern retail and avoid bakruptcy.
\end{abstract}

Keywords: Product, Price, Place, Promotion Retail Modern, Traditional Retail, Business continuity.

\section{PENDAhULUAN}

\section{Latar Belakang}

Di era globalisasi sekarang ini kegiatan bisnis khususnya pemasaran dari waktu ke waktu semakin meningkat. Sampai saat ini, kehidupan nyaris tidak pernah terlepas dari pasar, sebagai tempat dan sarana jual-beli berbagai komoditas. Sesuai dengan perkembangannya, dikenal adanya ritel tradisional dan ritel modern. ritel tradisional biasanya menampung banyak penjual yang dilaksanakan dengan manajemen sederhana tanpa adanya perangkat teknologi modern yang mewakili golongan pedagang menengah ke bawah (Tambunan dkk., 2004:17). ritel modern dalam pengertian ini, diantaranya swalayan, minimarket, supermarket, dan hypermarket. Permasalahan mulai muncul ketika ritel modern bergerak secara bebas berdiri, tidak hanya di daerah perkotaan, tetapi juga menerobos ke pelosok-pelosok, tanpa adanya pengendalian yang jelas dan tegas dari berbagai pihak yang

\footnotetext{
1) jurnal ini merupakan bagian dari skripsi yang ditulis oleh Ongky Martha Dwiyananda, NIM:040914093 yang diuji pada tanggal 07 Agustus 2015
} 
berkepentingan dan menyebabkan berpindahnya para pembeli ritel tradisional ke ritel modern tersebut. Melalui berbagai keunggulan yang dimiliki, ritel modern telah mampu "menggusur" keberadaan ritel tradisional.

Sebenarnya, jika dilihat dari sisi bisnis dan profesionalisme, bukanlah sesuatu yang bermasalah. Jika diukur dari kemampuan dana yang dimilliki, bukanlah merupakan sesuatu yang salah, wajar dan boleh-boleh saja. Akan tetapi, jika dilihat dari dampak kemunculannya di tengahtengah tempat perbelanjaan masyarakat kecil, terdapat banyak pihak yang mungkin terdzalimi. Mungkin akan terdapat beberapa pedagang kecil yang gulung tikar. Jika sumber penghasilan di tutup, berapa jumlah keluarga yang akan mengalami kelaparan, berapa anak yang akan terbengkalai pendidikannya karena tidak adanya biaya, dan bagaimana dengan kelangsungan hidup selanjutnya.

Kebebasan dalam ekonomi Islam tersebut dibatasi dengan kemaslahatan dan kesejahteraan orang lain. Kebebasan itu masih tetap berlaku sepanjang tidak menimbulkan kedzaliman dan eksploitasi terhadap kepentingan orang lain. Pada dasarnya manusia diperintahkan untuk mencintai saudara sesama muslim, sebagaimana mencintai diri sendiri. Sesama muslim selayaknya satu tubuh yang akan merasakan kesakitan seluruh tubuhnya, jika terdapat bagian tubuhnya yang terluka (Djazuli, 2003:78). Begitu indah nilai-nilai ini jika diterapkan dalam kehidupan ekonomi.
Banyak orang mulai beralih ke ritel modern seperti pusat belanja ini untuk berbelanja, Mukbar (2007:4) mengatakan bahwa ancaman yang muncul dari keberadaan swalayan antara lain karena mematikan ritel-ritel tradisional karena adanya pergeseran kebiasaan konsumen dan terkait permasalahan perekonomian lokal. Perputaran vang di daerah, awalnya sebagian besar perputaran vang tersebut merupakan konstribusi dari UKM namun seiring dengan berkurangnya UKM dan ritel tradisonal akibat kalah bersaing dengan ritel modern, maka secara otomatis mengecilkan konstribusi mereka. Implementasi nilai-nilai moralitas dalam pasar merupakan tugas personal bagi setiap pelaku pasar. Bagi seorang muslim ini merupakan wujud keimanan kepada Allah SWT. Karena penghargaan ajaran Islam terhadap mekanisme pasar dari ketentuan Allah bahwa perniagaan harus dilakukan secara baik dengan rasa suka sama suka.

Namun pada dasarnya setiap kegiatan ekonomi yang dilakukan selama tidak bertentangan dengan hukum syara' adalah boleh, begitu juga dengan proses jual beli dan pemasaran yang dilakukan oleh ritel-ritel modern. Islam masa kini sangat membutuhkan pandangan ekonomi yang jernih tentang apa yang diharapkan dan bagaimana sesuatu itu dilakukan. Sistem ekonomi yang bisa merealisasikan bauran pemasaran sesuai dengan ajaran islam, sehingga kemiskinan bisa dientaskan dan kesejahteraan bisa dinikmati semua penduduk. Alasan 
peneliti mengambil objek ritel modern adalah didasarkan atas keprihatinan peneliti terkait fenomena mulai dari sepinya pembeli, berkurangnya omset penjualan sampai gulung tikarnya ritel-ritel tradisional yang berada di Gresik. Seharusnya perlu diberlakukan aturan aturan terkait pendirian ritel modern saat ini sesuai dengan prinsip bauran pemasaran islami, sehingga tidak terjadi kezaliman seperti matinya usaha orang lain dan supaya terciptanya kemashlahatan ummat.

Berdasarkan paparan diatas peneliti tertarik untuk melakukan penelitian dengan judul "Pengaruh Produk, Harga, Tempat, Promosi Ritel Modern Terhadap Keberlangsungan Usaha Ritel Tradisional di Gresik".

\section{Rumusan Masalah}

Berdasar latar belakang yang telah dipaparkan, maka rumusan masalah yang diajukan pada penelitian ini adalah

1. "Apakah produk ritel modern berpengaruh terhadap keberlangsungan usaha ritel tradisional di Gresik?"

2. "Apakah harga ritel modern berpengaruh terhadap keberlangsungan usaha ritel tradisional di Gresik?"

3. "Apakah tempat ritel modern berpengaruh terhadap keberlangsungan usaha ritel tradisional di Gresik?"

4. "Apakah promosi ritel modern berpengaruh terhadap keberlangsungan usaha ritel tradisional di Gresik?"

5. "Apakah produk, harga, tempat, promosi ritel modern secara simultan berpengaruh terhadap keberlangsungan usaha ritel tradisional di Gresik?"

\section{Tujuan Penelitian}

Berdasarkan latar belakang dan rumusan masalah yang dipaparkan dan dijelaskan diatas, maka tujuan dari penelitian tersebut adalah untuk menguji dan menganalisis pengaruh produk, harga, tempat, promosi ritel modern secara parsial dan simultan terhadap keberlangsungan usaha ritel tradisional di Gresik.

\section{LANDASAN TEORI}

\section{Definisi Ritel}

Berbagai definisi ritel telah dikemukakan oleh para ahli, dimana semuanya memiliki maksud dan tujuan yang sama yaitu untuk merumuskan pengertian ritel.

Ritel adalah suatu penjualan dari sejumlah komoditas kepada konsumen. Ritel adalah semua usaha bisnis yang mengarahkan secara langsung kemampuan pemasarannya untuk memuaskan konsumen akhir berdasarkan organisasi penjualan barang dan jasa sebagai inti dari distribusi (Gilbert, 2003:6).

\section{Definisi Ritel Modern}

Regulasi pemerintah mengenai bisnis ritel diberlakukan (Perpres RI No. 112, 2007) tentang Penataan dan Pembinaan Pasar Tradisional, Pusat Perbelanjaan dan Ritel Modern. Ritel modern merupakan ritel 
dengan sistem pelayanan mandiri, menjual berbagai jenis barang secara eceran yang berbentuk Minimarket, Supermarket, Department Store, Hypermarket ataupun grosir yang berbentuk Perkulakan. Batasan ritel modern ini dipertegas di pasal 3, dalam hal luas lantai penjualan sebagai berikut:

a) Minimarket, kurang dari $400 \mathrm{~m} 2$ (empat ratus meter per segi)

b) Supermarket, $400 \mathrm{~m} 2$ (empat ratus meter per segi) sampai dengan $5.000 \mathrm{~m} 2$ (lima ribu meter per segi)

c) Hypermarket, diatas $5.000 \mathrm{~m} 2$ (lima ribu meter per segi)

d) Department Store, diatas $400 \mathrm{~m} 2$ (empat ratus meter per segi)

e) Perkulakan, diatas $5.000 \mathrm{~m} 2$ (lima ribu meter per segi).

\section{Definisi Ritel Tradisional}

Ritel tradisional atau juga bisa disebut pasar tradisional adalah pasar yang dibangun dan dikelola oleh Pemerintah. Daerah, Swasta, Badan Usaha Milik Negara dan Badan Usaha Milik Daerah, termasuk kerjasama swasta dengan tempat usaha berupa toko, kios, los dan tenda yang dimiliki/ dikelola oleh pedagang kecil, menengah, swadaya masyarakat atau koperasi dengan usaha skala kecil, modal kecil dan dengan proses jual beli barang dagangan melalui tawar-menawar (Pepres RI No. 112, 2007).

Pasar tradisional adalah pasar umum yang menjual barang-barang kebutuhan sehari-hari. Tegasnya, pasar tradisional berarti pasar yang menjual barang kebutuhan sehari-hari, dan secara resmi diakui oleh pemerintah. Menurut pengertiannya, pasar merupakan suatu tempat bagi manusia dalam mencari keperluan sehari-harinya (Anwar, 2001:4).

\section{Bauran Pemasaran dalam Berbagai Perspektif}

Pemasaran mempunyai fungsi yang sangat penting dalam mencapai keberhasilan dan keberlangsungan usaha. Dalam mencapai keberhasilan pemasaran, setiap pelaku usaha perlu menyusun strategi pemasaran yanag efektif dengan mengkombinasikan elemen-elemen dalam bauran pemasaran. Bauran pemasaran menurut Kotler (2008:62) "bauran pemasaran adalah kumpulan alat pemasaran taktis terkendali - produk, harga, tempat, dan promosi - yang diperlukan perusahaan untuk menghasilkan respon yang diinginkannya di pasar sasaran. Ada empat variabel dalam bauran pemasaran, yaitu:

1. Produk/Product adalah kombinasi barang dan jasa yang ditawarkan perusahaan kepada pasar sasaran.

2. Harga/Price adalah jumlah vang yang harus dibayar pelanggan untuk memperoleh produk.

3. Tempat/Place meliputi kegiatan perusahaan yang membuat produk tersedia bagi pelanggan sasaran.

4. Promosi/Promotion berarti aktivitas yang menyampaikan manfaat produk dan membujuk pelanggan membelinya. 
Bauran Pemasaran Perspektif Islam

Yusanto dan widjajakusuma (2002:170) mengatakan bahwa dalam menggagas bisnis Islami haruslah memperhatikan implementasi syariat pada marketing mix. Marketing mix atau Bauran Pemasaran adalah seperangkat alat pemasaran yang digunakan perusahaan untuk terus-menerus mencapai tujuan pemasarannya pada pasar yang menjadi sasaran. Implementasi syariat dapat diterapkan dalam variabel-variabel marketing mix yakni product, price, place, dan promotion.

Berkaitan dengan bauran pemasaran konvensional, maka penerapan dalam syariah akan merujuk pada konsep dasar kaidah fiqih yakni "Alashlu fil-muamalah al-ibahah illa ayyadulla dalilun 'ala tahrimiha" yang berarti bahwa pada dasarnya semua bentuk muamalah boleh dilakukan kecuali ada dalil yang mengharamkannya (Kartajaya dan Sula, 2008:27). Berikut adalah marketing mix dalam perspektif syariah, yakni:

\section{Produk}

Islam memiliki batasan tertentu yang lebih spesifik mengenai definisi produk. ada tiga hal yang perlu dipenuhi dalam menawarkan sebuah produk :

1) Produk yang ditawarkan memiliki kejelasan barang, kejelasan ukuran/ takaran, kejelasan komposisi, tidak rusak/ kadaluarsa dan menggunakan bahan yang baik.
2) Produk yang diperjual-belikan adalah produk yang halal.

\section{Harga}

Islam dalam menentukan harga tidak boleh membanting harga guna menjatuhkan pebisnis lainnya. Islam tentu memperbolehkan pedagang untuk mengambil keuntungan. Karena hakekat dari berdagang adalah untuk mencari keuntungan. Namun, untuk mengambil keuntungan tersebut janganlah berlebihlebihan (Ghazali, 2001:308). Karena, jika harga yang ditetapkan adalah harga wajar, maka pedagang tersebut pasti akan unggul dalam kuantitas. Dengan kata lain, mendapat banyak keuntungan dari banyaknya jumlah barang yang terjual, dan tampak nyatalah keberkahan rizkinya (Ghazali, 2001:309). Dalam proses penentuan harga, Islam juga memandang bahwa harga haruslah disesuaikan dengan kondisi barang yang dijual.

3. Promosi

Pemasaran dalam tinjauan syariah menyandarkan pedoman etikanya pada nilai-nilai Islami yang terdapat dalam AlQuran dan Hadits. Promosi dalam tinjauan syariah harus sesuai dengan sharia compliance yang merefleksikan kebenaran, keadilan dan kejujuran kepada masyarakat. Segala informasi yang terkait dengan produk harus diberitahukan secara transparan dan terbuka sehingga tidak ada potensi unsur penipuan dan kecurangan dalam melakukan promosi. Promosi yang tidak sesuai dengan kualitas atau kompetensi, 
contohnya promosi yang menampilkan imajinasi yang terlalu tinggi bagi konsumennya, adalah termasuk dalam praktik penipuan dan kebohongan. Untuk itu promosi yang semacam tersebut sangat dilarang dalam Islam (Kartajaya dan Sula, 2008:178).

4. Tempat/Distribusi

Dalam menentukan place atau saluran distribusi, perusahaan Islami harus mengutamakan tempat-tempat yang sesuai dengan target market, sehingga dapat efektif dan efisien. Sehingga pada intinya, dalam menentukan marketing-mix harus didasari pada prinsip-prinsip keadilan dan kejujuran. Yusanto dan Widjajakusuma (2002:21) berpendapat perbedaan antara bisnis Islami dan nonIslami terletak pada aturan halal dan haram, sehingga harus terdapat kehatihatian dalam menjalankan strategi.

\section{Keberlangsungan Usaha}

Keberlangsungan usaha adalah kemampuan suatu badan usaha untuk dapat bersaing dengan usaha lain sehingga usahanya terus berlangsung, dapat berkembang dengan baik dan terhindar dari kebangkrutan atau biasa disebut pailit. Dalam penulisan ini, peneliti menghubungkan keberlangsungan usaha dengan teori kebangkrutan.

\section{Hipotesis}

Berdasarkan permasalahan yang telah dirumuskan, tujuan penelitian serta landasan teori yang telah disebutkan sebelumnya, maka hipotesis yang dapat dirumuskan dalam penelitian ini adalah produk, harga, tempat dan promosi ritel modern secara parsial dan simultan memiliki pengaruh terhadap keberlangsungan usaha ritel tradisional.

\section{METODE PENELITIAN}

Pendekatan penelitian yang digunakan dalam penelitian ini adalah pendekatan kuantitatif, yang bertujuan untuk menguji hipotesis, dengan data yang terukur dan menghasilkan kesimpulan yang dapat digeneralisir. Langkah awal dalam melakukan penelitian kuantitatif dimulai dengan menentukan hipotesis, langkah selanjutnya membuat model analisis, indentifikasi variabel, definisi operasional, pengumpulan data (primer maupun sekunder) berdasarkan populasi dan sampel penelitian, serta melakukan analisis. Variabel yang digunakan dalam penelitian ini dapat diidentifikasikan menjadi 2 (dua) variabel, yaitu:

a. Variabel independen (X), yaitu produk, harga, tempat dan promosi ritel modern.

b. Variabel dependen (Y), yaitu keberlangsungan usaha ritel tradisional.

\section{Definisi Operasional Variabel}

Definisi operasional merupakan ketentuan yang didasarkan pada hal yang dapat diamati, sehingga dimungkinkan untuk dibuat aplikasi khusus dalam merancang alat penelitian atau kuesioner.

Uraian masing-masing variabel akan dijelaskan sebagai berikut :

Pengaruh Produk, Harga, tempat, Promosi Ritel Modern

Variabel ini menggambarkan pengaruh produk, harga, tempat dan promosi ritel modern terhadap 
keberlangsungan usaha ritel tradisional. Penjelasan mengenai produk, harga, tempat dan promosi ritel modern tersebut akan dijelaskan sebagai berikut:

a. Produk ritel modern meliputi :

1. Produk yang ditawarkan di ritel modern lebih lengkap.

2. Kualitas produk yang ada di ritel modern lebih baik.

3. Kemasan produk yang ada di ritel modern lebih menarik.

4. Variasi untuk produk sejenis lebih bermacam-macam.

b. Harga ritel modern meliputi :

1. Harga yang ditawarkan ritel modern lebih murah.

2. Potongan harga yang diberlakukan ritel modern lebih banyak.

3. Pemberlakuan harga khusus anggota member di ritel modern membuat harga jadi lebih rendah.

4. Pemberian Cash back atau pengembalian sejumlah vang apabila berbelanja dengan nominal tertentu di ritel modern menjadikan harga semakin lebih rendah.

c. Tempat ritel modern meliputi :

1. Tempat berdirinya ritel modern lebih strategis.

2. Lahan parkir yang disediakan ritel modern lebih luas.

3. Tersedianya ruangan ber AC membuat konsumen lebih betah belanja di ritel modern.

4. Ritel modern memiliki tempat yang lebih rapi dan bersih.
5. Tersedianya keranjang belanja di tempat ritel modern membuat pembeli lebih nyaman belanja disana.

d. Promosi ritel modern meliputi :

1. Pemasangan spaduk yang dilakukan ritel modern di pinggir jalan menarik perhatian konsumen untuk berbelanja disana.

2. Iklan promosi beli 1 gratis 1 yang ditawarkan ritel modern lebih menarik.

3. Promosi undian berhadiah di ritel modern menarik perhatian banyak pelanggan.

4. Promosi pemberian hadiah langsung yang ditawarkan ritel modern jika belanja dengan nominal tertentu menarik perhatian konsumen untuk berbelanja disana.

5. Penyebaran brosur ke rumahrumah warga yang dilakukan ritel modern membuat pelanggan beralih berbelanja disana.

\section{Keberlangsungan Usaha Ritel Tradisional}

Yang dimaksud keberlangsungan usaha disini Keberlangsungan usaha adalah kemampuan suatu badan usaha untuk dapat bersaing dengan usaha lain sehingga usahanya terus berlangsung, dapat berkembang dengan baik dan terhindar dari kebangkrutan atau likuidasi perusahaan atau penutupan perusahaan atau insolvabilitas (Hadi, 2008:57). Target yang telah dicapai dengan pertumbuhan setiap tahunnya harus dijaga keberlangsungannya agar perusahaan 
dapat eksis dalam kurun waktu yang lama. Upaya keberlangsungan usaha ini tentu harus memperhatikan koridor syariah. Faktor-faktor yang mempengaruhi keberlangsungan usaha ritel tradisional setelah disesuaikan adalah :

1. Berkurangnya jumlah pelanggan.

2. Penurunan penjualan barang.

3. Kesulitan mengembangkan usaha.

4. Kesulitan mendapatkan keuntungan/laba

5. Berkurangnya dana untuk kulakan.

6. Bertambah banyak barang yang kadaluarsa.

7. Menumpuknya hutang kepada pemberi pinjaman modal.

8. Penurunan jumlah pemesanan barang.

\section{Prosedur Pengumpulan Data}

Pengumpulan data yang digunakan dalam penelitian ini menggunakan dua cara, yaitu :

1. Studi Lapangan

Peneliti terlibat secara langsung ke lokasi yang menjadi objek penelitian untuk menyebarkan kuisioner kepada responden, dimana dalam hal ini adalah pemilik usaha ritel tradisional.

2. Studi Kepustakaan

Mempelajari data berupa jurnal dan text book serta referensi yang relevan dari internet untuk mendapat landasan teoritis dalam pemecahan masalah.

\section{Teknik Analisa Data}

Model analisis yang digunakan dalam penelitian ini berbentuk regresi linier berganda. Model analisis ini digunakan untuk mengetahui pengaruh variabel independen terhadap variabel dependen. Analisis dilakukan dengan menggunakan metode kuantitatif regresi linier berganda, kemudian dilakukan pengujian hipotesis. Untuk membuktikan hipotesis penelitian, dapat dilakukan dengan uji $t$ dan uji $F$.

\section{HASIL DAN PEMBAHASAN}

\section{Hasil Analisis Regresi Linear Berganda}

Tabel 1.

Hasil Uji Regresi Linier Berganda

\begin{tabular}{|c|r|c|c|}
\hline Variabel & $\begin{array}{c}\text { Koefisien } \\
\text { Regresi }\end{array}$ & t hit & $\begin{array}{c}\text { Signifi } \\
\text { kansi }\end{array}$ \\
\hline Konstanta & 0.639 & 2.205 & 0.033 \\
\hline Produk & 0.266 & 2.631 & 0.012 \\
\hline Harga & 0.013 & 0.146 & 0.884 \\
\hline Tempat & 0.265 & 2.389 & 0.021 \\
\hline Promosi & 0.350 & 2.575 & 0.013 \\
\hline
\end{tabular}

F hitung $=32,547$

Signifikansi $=0,000$

Korelasi berganda $(R)=0,862$

Koefisien determinasi $\left(R^{2}\right)=0,720$

$\mathrm{N}=50$

Nilai dari koefisien determinasi dari

hasil regresi pada penelitian ini adalah 0,720 yang berarti bahwa produk, harga, tempat, promosi ritel modern secara bersama-sama berpengaruh terhadap keberlangsungan usaha ritel tradisional (Y) sebesar 0.720 atau $72 \%$ sedangkan sisanya sebesar 0,280 atau $28 \%$ dipengaruhi oleh variabel lain diluar variabel bebas yang digunakan dalam penelitian.

\section{Uji Hipotesis}

Uji F

Hasil pengujian menunjukkan nilai $\mathrm{F}$ hitung sebesar 32,547 dengan tingkat signifikansi 
uji F hitung adalah sebesar $0,000(p<0.05)$ berarti produk $\left(X_{1}\right)$, harga $\left(X_{2}\right)$, tempat $\left(X_{3}\right)$, promosi $\left(\mathrm{X}_{4}\right)$ ritel modern secara bersamasama berpengaruh signifikan terhadap keberlangsungan usaha ritel tradisional, sehingga dapat dikatakan $\mathrm{Ha}$ diterima kebenarannya.

Uji $\uparrow$

Pengujian hipotesis koefisien regresi secara parsial (uji t) ditunjukkan untuk mengetahui pengaruh variabel bebas secara parsial terhadap variabel tergantung dalam satu model. Hasil uji parsial dipaparkan selengkapnya pada Tabel berikut:

Tabel 2.

Pengambilan Keputusan dari Hasil Pengujian thitung

\begin{tabular}{|c|c|c|}
\hline Variabel & Signifikansi & Keterangan \\
\hline Produk & $0.012<0,05$ & $\begin{array}{c}\text { Ada pengaruh } \\
\text { signifikan }\end{array}$ \\
\hline Harga & $0.884>0,05$ & $\begin{array}{c}\text { Tidak ada } \\
\text { pengaruh } \\
\text { signifikan }\end{array}$ \\
\hline Tempat & $0.021<0,05$ & $\begin{array}{c}\text { Ada pengaruh } \\
\text { signifikan }\end{array}$ \\
\hline Promosi & $0.013<0,05$ & $\begin{array}{c}\text { Ada pengaruh } \\
\text { signifikan }\end{array}$ \\
\hline
\end{tabular}

Berdasarkan perbandingan nilai

signifikansi nilai $\dagger$ dengan 0,05 ternyata dapat disimpulkan bahwa variabel produk $\left(X_{1}\right)$, tempat $\left(X_{3}\right)$, promosi $\left(X_{4}\right)$ ritel modern memiliki pengaruh signifikan terhadap keberlangsungan usaha ritel tradisional sedangkan variabel harga $\left(X_{2}\right)$ tidak ada pengaruh signifikan terhadap keberlangsungan usaha ritel tradisional.

\section{Pembahasan}

Penelitian ini berfokus untuk mencari pengaruh dari produk, harga, tempat dan promosi ritel modern terhadap keberlangsungan usaha ritel tradisional serta mencari tahu bagaimana pandangan pemasaran islami terkait pemasaran yang dijalankan oleh ritel modern. Peneliti menggunakan 4 variabel yang terdiri dari variabel produk, harga, tempat dan promosi untuk mengetahui apakah keempat variabel tersebut memiliki pengaruh signifikan terhadap terancamnya keberlangsungan usaha ritel tradisional di kota Gresik.

Pada bagian ini akan dilakukan pembahasan atas hasil penelitian yang sudah dilakukan. Sebagaimana yang sudah diketahui bersama dalam uji kebenaran hipotesis, telah dilakukan uji untuk membuktikan adanya pengaruh dari 4 variabel pemasaran ritel modern terhadap keberlangsungan usaha ritel tradisional di Gresik. Uji yang dilakukan yaitu uji $F$ dan uji t. untuk mengetahui apakah variabel-variabel tersebut memiliki pengaruh yang signifikan. Hasil pengujian $F$ atau pengujian secara simultan menunjukkan bahwa produk, harga, tempat dan promosi ritel modern secara bersama sama berpengaruh signifikan terhadap terancamnya keberlangsungan usaha ritel tradisional hal tersebut ditunjukkan dari nilai $F$ hitung sebesar 32,547 dengan tingkat signifikansi dibawah 0,05 yaitu 0,000. Sementara dari hasil pengujian t hitung hanya pada variabel produk, tempat dan promosi yang menunjukkan tingkat signifikan $<0,05$, yaitu 0,012 pada variabel produk, 0,021 pada variabel tempat dan 0,013 pada variabel promosi. Hasil tersebut 
menunjukan bahwa secara parsial atau secara individu variabel produk, tempat dan promosi ritel modern memiliki pengaruh signifikan terhadap terancamnya keberlangsungan usaha ritel tradisional. Sedangkan pada variabel harga menunjukkan tingkat signifikansi > 0,05 yaitu 0,884. Hasil tersebut menunjukkan bahwa pada variabel harga ternyata tidak memiliki pengaruh yang signifikan terhadap terancamnya keberlangsungan usaha ritel tradisional.

\section{SIMPULAN DAN SARAN}

\section{Simpulan}

Simpulan penelitian Pengaruh Produk, Harga, Tempat, Promosi Ritel Modern Terhadap Keberlangsungan Usaha Ritel Tradisional di Gresik adalah dari keempat variabel yaitu produk, harga, tempat dan promosi ritel modern berdasarkan hasil uji † ternyata tidak semua variabel memiliki pengaruh signifikan terhadap keberlangsungan usaha ritel tradisional. Hanya pada variabel produk, tempat dan promosi ritel modern yang memiliki pengaruh signifikan terhadap keberlangsungan usaha ritel tradisional. Sementara pada variabel harga tidak memiliki pengaruh yang signifikan terhadap keberlangsungan usaha ritel tradisional. konsep pemasaran yang dilakukan ritel modern tidak sesuai dengan konsep pemasaran Islami, hal itu terbukti dari produk yang dijual terdapat minuman keras atau khamar yang diharamkan oleh Islam serta bentuk promosi yang mengandung unsur penipuan. Para pengusaha ritel tradisional juga mengeluhkan turunnya pendapatan setelah berdirinya ritel modern disekitar usahanya. Hal tersebut dikarenakan ritel tradisional kalah bersaing dengan ritel modern dari segi produk, tempat serta promosi. Dari penjelasan tersebut dapat disimpulkan bahwa keberadaan ritel modern memberikan pengaruh negatif terhadap keberlangsungan usaha ritel tradisional di kota Gresik.

\section{Saran}

Saran yang direkomendasikan setelah penelitian "Pengaruh Produk, Harga, Tempat, Promosi Ritel Modern Terhadap Keberlangsungan Usaha Ritel Tradisional di Gresik" adalah:

\section{Bagi Pemerintah Kota Gresik}

Diharapkan kepada pemerintah Kota Gresik dan beberapa instansi yang terlibat di dalamnya lebih memperhatikan fenomena banyaknya pendirian ritel modern seperti alfamart, indomart, alfamidi yang berdekatan dengan ritel tradisional. Seharusnya pemerintah Kota Gresik memberikan aturan yang tegas terhadap ijin pendirian ritel modern dan juga memberikan batas jarak minimal letak berdirinya ritel modern terhadap ritel tradisional serta membatasi jumlah maksimal pendirian ritel modern pada wilayah-wilayah tertentu. Sehingga para pemilik usaha ritel tradisional tidak merasa terancam keberlangsungan usahanya. $\mathrm{Hal}$ ini bertujuan agar kemashlahatan umat dapat terwujud.

\section{Bagi Pemilik Usaha Ritel Tradisional}

Bagi pengusaha ritel tradisional diharapkan lebih kreatif dan inovatif 
dalam memasarkan berbagai produk yang dia tawarkan kepada konsumen, serta memberikan pelayanan yang lebih baik kepada konsumen dan juga diharapkan kepada pengusaha ritel tradisional memahami konsep serta strategi pemasaran sehingga mampu bersaing dengan kemunculan ritel modern saat ini.

\section{Bagi Penelitian Selanjutnya}

Diharapkan penelitian ini dapat digunakan sebagai bahan acuan untuk melakukakan penelitian selanjutnya. Peneliti menyadari bahwa penelitian ini memiliki banyak keterbatasan. Penelitian selanjutnya diharapkan dapat meneliti mengenai pengaruh keberadaan ritel modern terhadap keberlangsungan usaha ritel tradisional dengan perspektif islami yang lebih luas dan responden yang lebih banyak sehingga dapat dihasilkan hasil penelitian yang lebih global dan umum. Oleh karena itu, keterbatasan penelitian ini akan memberikan peluang bagi penelitian selanjutnya untuk melakukan pengembangan penelitian.

\section{DAFTAR PUSTAKA}

Abdul, Hakim. 2001. Statistika Deskriptif untuk Ekonomi dan Bisnis, Edisi Pertama, Cetakan Pertama. Yogyakarta: Ekonisia.

Adnan, M.A. 2000. Analisis Tingkat Kesehatan Perusahaan untuk Memprediksi Potensi Kebangkrutan dengan Pendekatan Metode Altman (Kasus Pada Sepuluh Perusahaan di
Indonesia). Disertasi tidak diterbitkan. Universitas Islam Indonesia. Yogyakarta. Al-Ghazali, Abdul Hamid. 2001. Meretas Jalan Kebangkitan Islam - Peta Pemikiran Hasan Al Banna. Solo: Era Intermedia

Al-Qur'an dan Terjemahanya. 2005. Syamil Al Qur'an. Bandung: PT. Syaamil Cipta Media.

Anshory, M. dan S. Iswati. 2009. Metodologi Penelitian Kuantitatif. Surabaya: Airlangga University Press.

Anwar, M. 2001. Pedoman Pembinaan Pasar Tradisional. Jakarta. Dirjen Departemen Perindustrian dan Perdagangan.

Assauri, Sofjan. 2007. Manajemen

Pemasaran. Jakarta: PT. Raja Grafindo Persada.

Djazuli, A. 2003. Fiqh Siyasah: Implementasi Kemaslahatan Umat dalam Ramburambu Syari'ah. Jakarta: Prenada Media.

Fukuyama, Francis. 1992. The End of History and The Last Man. Yogyakarta: Qalam.

Ghozali, Imam. 2011. Aplikasi Analis MultiVariate dengan Program SPSS IBM SPSS 19. Semarang : Badan Penerbit Universitas Diponegoro.

Gilbert, David. 2003. Retail Marketing Management. Second Edition. London: Prentice Hall.

Hadi, Syamsul. 2008. Pemilihan Prediktor Delisting Terbaik (Perbandingan antara The Zmijewski Model, The Altman Model, dan The Springate Model). Yogyakarta: Universitas Islam Indonesia. 
Harmawan Kartajaya dan Muhammad Syakir Sula. 2008. Syariah marketing. Jakarta: Mizan Pustaka.

Indriantoro, Nur dan Bambang Supomo.1999. Metodologi Penelitian Bisnis: untuk Akuntansi dan Manajemen. Yogyakarta: BPFE Yogyakarta.

Islabi. 1997. Konsepsi Ekonomi Ibnu Taimiyah. Surabaya: PT Bina IImu Offset. Karim, Adiwarman A. 2001. Ekonomi Islam Suatu Kajian Kontemporer, Jakarta: Gema Insani.

Kotler, Philip dan A. B. Susanto. 2008. Manajemen Pemasaran di Indonesia. Buku 2. Jakarta: Salemba Empat dan Pearson Education Asia Pte.Ltd.

Kusmayadi. 2000. Metode Penelitian Kuantitatif, Kualitatif. Jakarta: Gramedia Pustaka Utama.

Kusumo, Putro Adhi 2007. Pengaruh

Efektifitas Bauran Pemasaran

(Marketing Mix) Pasar Modern

Terhadap Tingkat Transaksi Bisnis di Pasar Tradisional (Studi Kasus di Pasar Klewer). Surakarta. Universitas Muhammadiyah Surakarta. Levy, Michael \& Barton A Weitz. 2007. Retailing Management, 6th Edition. New York: McGraw-Hill .

Malhotra, Naresh. K. 2002. Basic Marketing Research: Application to Contemporary Issues. International Edition. New Jersey: Prentice Hall, Inc.

Marx, Karl \& Frederick Engels. 1995. Manifesto of the Communist Party, dalam Karl Marx and Frederick Engels Selected Works. Moscow: Progress Publishers.
Mukbar, Deni. 2007. Denyut Usaha Kecil di Pasar Tradisional dalam Himpitan Hipermarket. Jurnal Analisis Sosial, (Online),

http://books.google.co.id/books?id=9je BKQycgB8C\&pg=PA1 18\&dq=ketahana $\mathrm{n}+$ dan+kerentanan+usaha+kecil\&hl=id \&sa $=X \& e i=U 65 R T 46 T I Y n p r Q e 3 j r n W D Q \& v$ ed=0CDoQ6AEWAA\#v=onepage $\& \mathrm{q}=\mathrm{k}$ etahanan\%20dan\%20kerentanan\%20us aha\%20kecil\&f=false diakses pada tanggal 28 Juni 2014.

Pandin, M. L. 2009. Potret Bisnis Ritel di Indonesia: Pasar Modern, (Online), http://www.bni.co.id/portals/0/docum ent/2009Marchritel\%20business.pdf diakses pada 16 Juni 2014.

Paul, Omerold. 1997. Matinya Ilmu Ekonomi (Menuju Ekonomi Baru). Jakarta: KPG Gramedia.

Republik Indonesia. 2007. Peraturan Presiden No 112 Tahun 2007 tentang Penataan dan Pembinaan Pasar Tradisional, Pusat Perbelanjaan dan Toko Modern. Jakarta: Kementrian Perindustrian Republik Indonesia.

Reza, Safitri Ahmad. 2010. Pengaruh Ritel Modern Terhadap Kesejahteraan Pasar Tradisional di Surabaya. Surabaya. Universitas Negeri Surabaya: Skripsi tidak diterbitkan.

Ricardo, D. 1998. The Principles of Political Economy and Taxation. London: J. M. Dent and Son.

Smith, Adam. 2000. The Wealth of Nation. London: Modern Library.

Solimun. 2000. Kaidah dan Metode Analisis Data. Malang: Gramedia. 
Sopiah dan Syihabudhin. 2008.

Manajemen Bisnis Ritel. Edisi I.

Yogyakarta: ANDI.

Sugiyono. 2010. Metodologi Penelitian

Kombinasi (Mixed Methods). Bandung:

CV Alfabeta.

Suprapto, J. 2002. Pengukuran Tingkat

Kepuasan Pelanggan untuk Menaikkan

Pangsa Pasar. Jakarta: Rineka Cipta.

Suryani, Desi. 2010. Analisis Dampak

Kehadiran Minimarket Terhadap Kinerja

Pedagang Pasar Tradisional

Peterongan Kabupaten Jombang.

Malang. Universitas Brawijaya : Skripsi

tidak diterbitkan.

Tambunan, Tulus TH, dkk. 2004. Kajian

Persaingan dalam Industri Retail.

Jakarta: Komisi Pengawas Persaingan

Usaha (KPPU).

www.gresikkab.go.id diakses pada

tanggal 22 April 2015 pukul 09.30

Yusanto M dan M. K. Widjajakusuma. 2002.

Menggagas Bisnis Islami. Jakarta:

Gema Insani. 